\title{
Evaluating self-buffering ionic liquids for
}

\section{biotechnological applications}

Sze Ying Lee ${ }^{\mathrm{a}}$, Filipa A. Vicente ${ }^{\mathrm{b}}$, Francisca A. e Silva ${ }^{\mathrm{b}}$, Tânia E. Sintra ${ }^{\mathrm{b}}$, Mohamed Taha ${ }^{\mathrm{b}}$, $\underline{\text { Ianatul Khoiroh }}^{\mathrm{a}}$, João A. P. Coutinho ${ }^{\mathrm{b}}$, Pau Loke Show ${ }^{\mathrm{a}}$, Sónia P. M. Ventura ${ }^{\mathrm{b} *}$

${ }^{a}$ Department of Chemical and Environmental Engineering, Faculty of Engineering, University of Nottingham Malaysia Campus, Jalan Broga, Semenyih 43500, Selangor Darul Ehsan, Malaysia.

${ }^{b}$ CICECO - Aveiro Institute of Materials, Department of Chemistry, University of Aveiro, 3810-193 Aveiro, Portugal.

*Corresponding author:

E-mail: spventura@ua.pt; Fax: +351 234370 084; Tel: +351 234401507 


\begin{abstract}
A new range of Good's buffer ionic liquids (GB-ILs), displaying simultaneously the properties of ionic liquids and Good's buffers, were synthesized by combination of Good's buffers anions (MOPSO, BES, TAPSO and CAPSO) and tetrabutylammonium, tetrabutylphosphonium and cholinium cations via an acid-base neutralization reaction. The activity and stability of a lipolytic enzyme from Pseudomonas cepacia in aqueous solutions of these buffers were evaluated and the results show their advantage as media for enzymatic reactions when compared to conventional phosphate buffers. Moreover aqueous biphasic systems (ABS) composed by these GB-ILs and potassium citrate were investigated and shown to be highly effective and selective for the partitioning of the lipolytic enzyme into the GB-IL-rich phase. The results allow the development of an efficient and biocompatible process combining the self-buffering and enzyme-stabilizing properties of the GB-ILs in the reaction step, with the advantages of GB-ILs as extraction solvents in ABS.
\end{abstract}

KEYWORDS: Good's buffer ionic liquids, self-buffering GB-ILs, aqueous biphasic systems, enzyme-stabilizing systems, biocatalysis and bioseparation 


\section{Introduction}

Ionic liquids (ILs) have been proposed as environmental benign solvents ${ }^{1}$ to replace harmful volatile organic compounds due to their unique properties, ${ }^{2}$ thus enhancing their recycling ability and product recovery, and improving the safety of (bio)chemical processes. ${ }^{3}$ The interest in biotechnological applications of ILs is growing not only for enzyme catalysis ${ }^{4-}$ ${ }^{8}$ but also for bioseparation process. ${ }^{9-10}$ Their potential as media for biocatalytic reactions with remarkable yields ${ }^{11}$ has been demonstrated, in addition to their enantioselectivity ${ }^{12}$ and enzyme stability. ${ }^{13}$ In bioseparations water miscible-ILs hold great potential as a feasible alternative for phase forming agents in aqueous biphasic systems (ABS) to replace conventional polymer and/or salt-rich phases, ${ }^{14}$ for the purification of various enzymes including alcohol dehydrogenases, ${ }^{15}$ lysozyme, ${ }^{16}$ cyclodextrin glycosyltransferase, ${ }^{17}$ peroxidases, ${ }^{18}$ and lipases. ${ }^{19-22}$

The need to maintain a stable $\mathrm{pH}$ during an enzyme-catalysed reaction is well established. ${ }^{23-24}$ Therefore, most applications of ILs in biotechnological field involve the addition of buffers to stabilize hydrogen ion concentrations during enzymatic reaction. However, this is not adequate to maintain a precise $\mathrm{pH}$ control in IL systems as the intrinsic acidity or basicity of hydrophilic ILs might destroy the buffer effect, ${ }^{25}$ depending on the ILs concentrations applied. Additionally, ionic liquid-based ABS (IL-based ABS) for enzyme extraction are always limited by the selection of a buffer in order to prevent the loss of activity during the extraction process. The phosphate buffer is most commonly used, ${ }^{26}$ and the use of organic salts, such as citrates is seldom considered when dealing with labile enzymes as these systems create a $\mathrm{pH}$ of 8 to 10 , and lack buffering capacity to maintain the optimum $\mathrm{pH}$ during the extraction process, ${ }^{27}$ thus limiting $\mathrm{ABS}$ formation ${ }^{28}$ and the partitioning behaviour of enzymes. ${ }^{16}$ It would, therefore, be important to find alternative approaches. 
In this work, the design of ILs with self-buffering and enzyme-compatible behaviour was addressed. The use of self-buffering ILs in IL-based ABS offers further advantages compared to traditional buffers, namely the possibility of controlling salt precipitation/crystallization, since most ILs present low melting temperatures, exist in liquid state at room temperature, are miscible with water in the entire range of concentration, allowing the tailoring of the polarity of both phases due to the wide array of IL structures available. ${ }^{29}$ After the first report of the buffer-like ILs, ${ }^{30}$ recently, some works reported the synthesis of ILs with self-buffering properties $^{31-33}$ through the selection of anions derived from biological buffers, namely the Good's buffers (GBs). Besides the buffering ability, these GBs anions ${ }^{34}$ also conferred high biocompatibility to the synthesized ILs. The GBs anions Tricine, TES, CHES, HEPES and MES have been paired with alkylimidazolium, ${ }^{32}$ tetraalkylammonium, ${ }^{32}$ and cholinium cations $^{31,33}$ and these new ILs demonstrated self-buffering behaviour, low toxicity, ability to form ABS with inorganic and organic salts, thus revealing high protein stability. Yet, there is no literature available concerning these ILs in enzymatic systems.

In the present study, the synthesis of ILs based on GBs anions, with $\mathrm{pK}_{\mathrm{a}}$ values closer to the optimum $\mathrm{pH}$ of most enzymes was achieved. The anions chosen are MOPSO, BES, TAPSO and CAPSO with $\mathrm{pK}_{\mathrm{a}}$ values of $6.90,7.09,7.60$ and 9.60 , respectively, at $25^{\circ} \mathrm{C}$ and 0.1 M. The selected anions were coupled with cations belonging to the tetrabutylammonium, tetrabutylphosphonium, and cholinium ILs families in order to produce twelve Good's buffer ILs (GB-ILs). These cations were selected due to their characteristics reported in literature. ${ }^{35-}$ ${ }^{37}$ To further assess the GB-ILs produced the GB-ILs buffering capacity was validated and compared to the respective GBs. The toxicity of each GB and GB-IL towards the Vibrio fischeri marine bacteria also was characterized. The viability of GB-ILs as a benign medium to the enzymes was also investigated by measuring the activity of a lipase from Pseudomonas cepacia (recently reclassified as Burkholderia cepacia) in $0.05 \mathrm{M}$ and $1.0 \mathrm{M}$ aqueous solution 
of GB-ILs at $\mathrm{pH} 7.0$, after 4 hours of contact, and comparing with the phosphate buffer. Finally, the ability of the synthesized GB-ILs to form ABS with a biodegradable citrate-based salt was investigated and the partitioning behaviour of the lipase in the selected GB-ILsbased ABS was studied, aiming at evaluating the applicability of these GB-ILs in bioseparations.

\section{Experimental Section}

\section{Materials}

Tetrabutylammonium hydroxide solution (40 wt\% in $\mathrm{H}_{2} \mathrm{O}$ ), tetrabutylphosphonium hydroxide solution $\left(40 \mathrm{wt} \%\right.$ in $\mathrm{H}_{2} \mathrm{O}$ ), choline hydroxide solution $\left(46 \mathrm{wt} \%\right.$ in $\mathrm{H}_{2} \mathrm{O}$ ), 2hydroxy-3-morpholinopropanesulfonic acid (MOPSO, purity $\geq 99 \%$ ), 2-[bis(2hydroxyethyl)amino]ethanesulfonic acid (BES, purity $\geq 99 \%$, N[tris(hydroxymethyl)methyl]-3-amino-2-hydroxypropanesulfonic acid (TAPSO, purity $\geq 99$ \%), 3-(cyclohexylamino)-2-hydroxy-1-propanesulfonic acid (CAPSO, purity $\geq 99 \%$ ), potassium citrate tribasic monohydrate $\left(\mathrm{C}_{6} \mathrm{H}_{5} \mathrm{~K}_{3} \mathrm{O}_{7} \cdot \mathrm{H}_{2} \mathrm{O}\right.$, analytical grade), potassium phosphate monobasic $\left(\mathrm{KH}_{2} \mathrm{PO}_{4}\right.$, analytical grade), potassium phosphate dibasic $\left(\mathrm{K}_{2} \mathrm{HPO}_{4}\right.$, analytical grade), 4-nitrophenyl laurate ( $p$-NFL, purity $\geq 98.0 \%$, 4-nitrophenol ( $p$-NP, spectrophotometric grade), brilliant blue G-250 and the protein standard of bovine serum albumin (BSA) were supplied by Sigma-Aldrich. The enzyme used throughout this work was a lipase from P. cepacia (Burkholderia cepacia) powder purchased from Sigma-Aldrich. It should be highlighted that in this work P. cepacia is used, despite the fact that this microorganism was reclassified as Burkholderia cepacia, to maintain the commercial designation from Sigma-Aldrich, and thus the lipase name will be described along this work in accordance with the trade name, in order to allow the cross reference of these commercial lipase. Methanol (HPLC grade, purity $\geq 99.9 \%$ ), acetonitrile (HPLC grade, purity $\geq 99.9 \%$ ), dimethyl sulfoxide (DMSO), hydrochloric acid (HCL), ethanol, acetic acid, and 
orthophosphoric acid were acquired from Fisher Scientific, and sodium hydroxide $(\mathrm{NaOH})$ was purchased from Merck. Ultra-pure water treated by a Milli-Q integral water purification system was used throughout the work. All the stock solutions and buffers for polyacrylamide gel electrophoresis and pre-stained protein standards (broad range) were obtained from BioRad, and Proteosilver silver stain kit were purchased from Sigma-Aldrich.

\section{Methods}

\section{Synthesis of GB-ILs}

GB-ILs were synthesized by acid-base neutralization reaction of hydroxide solution of cations and GBs as detailed in Section S1 from Supporting Information (SI).

\section{GB-ILs' buffering capacity}

The $\mathrm{pH}$ titration profiles were established using a potentiometric titrator (Metrohm, model 904 Titrando) controlled using the Tiamo software version 2.3, and equipped with a 801 stirrer with stand and 805 dosimat with an exchange unit of $20 \mathrm{~mL}$, a $\mathrm{pH}$ glass electrode 6.0262.100a temperature sensor 6.1114.010. The $\mathrm{pH}$ electrode was previously calibrated with aqueous solutions of standard buffers of $\mathrm{pH} 4.0$ and 7.0. The acid-base titration was performed with $10 \mathrm{~mL}$ of an aqueous solution of each GB-ILs $(0.05 \mathrm{M})$ in a double-walled glass vessel at two different temperatures, 25 and $37^{\circ} \mathrm{C}$, which were controlled using a thermostatic water bath. The titrants used were $0.05 \mathrm{M}$ of $\mathrm{NaOH}$ and $0.05 \mathrm{M}$ of $\mathrm{HCl}$. The potentiometric titration measurements were performed in duplicate.

\section{Ecotoxicity analysis of GB-ILs}

The GB-ILs and GBs ecotoxicity was investigated using the standard Microtox liquidphase assay, which is based on the evaluation of the luminescence response of a marine bacteria, Vibrio fischeri strain NRRL B-11177, after exposure to each compound at $15^{\circ} \mathrm{C}$, as described elsewhere. ${ }^{38}$ The decrease in the toxicant concentration and the light output of the bacteria produced a dose/response relationship and the results were computed using the 
Microtox Omni Software version 4.1 to calculate the effective concentration associated with a $50 \%$ reduction in the luminescence from the marine bacteria $V$. fischeri, $\mathrm{EC}_{50}$, at the exposure time of 5, 15 and 30 minutes for all the GB-ILs and GBs.

\section{Enzyme activity of lipase in GB-ILs}

The lipolytic enzyme from P. cepacia was incubated in the aqueous solutions of phosphate buffers $\left(\mathrm{K}_{2} \mathrm{HPO}_{4} / \mathrm{KH}_{2} \mathrm{PO}_{4}\right.$ mixture), GBs and GB-ILs (pH 7.0, at both concentration of 0.05 $\mathrm{M}$ and $1.0 \mathrm{M})$ at $100 \mathrm{rpm}$ at $25 \pm 1{ }^{\circ} \mathrm{C}$ for 4 hours and the residual enzyme activity was assayed. The experiments were performed in triplicate for each compound. The results are presented in relative enzyme activity, as described in eq. 1.

Relative enzyme activity $=\frac{\mathrm{EA}_{\mathrm{GB}-\mathrm{ILs} / \mathrm{GBs}(0.05 \mathrm{M} / 1.0 \mathrm{M})}}{\mathrm{EA}_{\text {phosphate buffer }(0.05 \mathrm{M} / 1.0 \mathrm{M})}}$

\section{Potential of GB-ILs in ABS formation}

The ability of GB-ILs to form ABS with potassium citrate $\left(\mathrm{K}_{3} \mathrm{C}_{6} \mathrm{H}_{5} \mathrm{O}_{7}\right)$ was investigated and the experimental binodal curves determined using the cloud point titration method at 25 $\pm 1{ }^{\circ} \mathrm{C}$ and atmospheric pressure. The experimental procedure of determining ABS with ILs was adopted from other works performed and validated by us, ${ }^{26,39-40}$ using an analytical balance (Mettler Toledo, model AB204-S/FACT). All the calculations considering the mass fractions or molarity of the citrate-based salt were carried out discounting the complexed water presented in the commercial citrate-based salt. The experimental coexisting curves were fitted to eq. 2 :

$[\mathrm{IL}]=\mathrm{A} \exp \left[\left(\mathrm{B} \times\left[\mathrm{K}_{3} \mathrm{C}_{6} \mathrm{H}_{5} \mathrm{O}_{7}\right]^{0.5}\right)-\left(\mathrm{C} \times\left[\mathrm{K}_{3} \mathrm{C}_{6} \mathrm{H}_{5} \mathrm{O}_{7}\right]^{3}\right)\right]$

where [IL] and $\left[\mathrm{K}_{3} \mathrm{C}_{6} \mathrm{H}_{5} \mathrm{O}_{7}\right]$ are the weight fraction percentages of IL and potassium citrate, and $\mathrm{A}, \mathrm{B}$, and $\mathrm{C}$ are constants obtained by the regression of the experimental binodal curves. The tie-lines (TLs) and respective tie-line lengths (TLL) of several selected ternary phase diagrams were determined as described elsewhere. ${ }^{26-27,40}$ 


\section{Partitioning behaviour of lipolytic enzyme in GB-ILs-based ABS}

The total mass of GB-ILs-based ABS was $5.0 \mathrm{~g}$ and $0.1 \mathrm{wt} \%$ of commercial lipase from $P$. cepacia was added. The mixture $\mathrm{pH}$ was adjusted to 7.0 and measured at $25 \pm 1{ }^{\circ} \mathrm{C}$ using a pH meter (Fisher scientific, model accumet AB15 basic). The mixture was stirred in a vortex until all the components were dissolved. Then, the enzymatic solutions were centrifuged at $2500 \mathrm{rpm}$ for $15 \mathrm{~min}$ by a centrifuge (Eppendorf, model $5810 \mathrm{R}$ ), and placed in an incubator at $25{ }^{\circ} \mathrm{C}$ for at least 12 hours to reach equilibrium. After this period, both phases were carefully separated and their volume and weight were measured, and prepared for enzyme activity assay and protein assay. Triplicate independent runs were performed for each partitioning test and the result was expressed as the average of the three assays.

The partitioning behaviour of the lipolytic enzyme was studied by determining the partition coefficient of the enzyme, $K_{E}$, and total proteins, $K_{P}$, as defined by eqs. ( 3 and 4 ), and additionally, the enzyme recovery, $\mathrm{R}_{\mathrm{T}}^{\mathrm{E}}$, and protein recovery, $\mathrm{R}_{\mathrm{T}}^{\mathrm{P}}$, in the top GB-IL-rich phase,

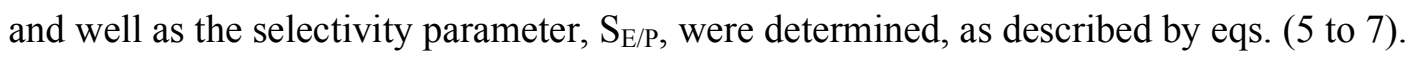

$$
\begin{aligned}
& \mathrm{K}_{\mathrm{E}}=\frac{\mathrm{EA}_{\mathrm{T}}}{\mathrm{EA_{B }}} \\
& \mathrm{K}_{\mathrm{P}}=\frac{\mathrm{C}_{\mathrm{T}}}{\mathrm{C}_{\mathrm{B}}} \\
& \mathrm{R}_{\mathrm{T}}^{\mathrm{E}}=\frac{100}{1+\frac{1}{\mathrm{R}_{\mathrm{V}} \mathrm{K}_{\mathrm{E}}}} \\
& \mathrm{R}_{\mathrm{T}}^{\mathrm{P}}=\frac{100}{1+\frac{1}{\mathrm{R}_{\mathrm{V}} \mathrm{K}_{\mathrm{P}}}} \\
& \mathrm{S}_{\mathrm{E} / \mathrm{P}}=\frac{\mathrm{K}_{\mathrm{E}}}{\mathrm{K}_{\mathrm{P}}}
\end{aligned}
$$


where $\mathrm{EA}_{\mathrm{T}}$ and $\mathrm{EA}_{\mathrm{B}}$ are the enzyme activity at the top and bottom phases, $\mathrm{C}_{\mathrm{T}}$ and $\mathrm{C}_{\mathrm{B}}$ are the total protein concentration at the top and bottom phases, and $R_{V}$ is the volume ratio of top and bottom phases.

\section{Enzyme activity assay}

The lipase activity was spectrophotometrically assayed using a UV-Vis spectrophotometer (Shimadzu, model UV-1800), as described in our earlier work. ${ }^{41}$ The substrate solution was prepared by dissolving $0.018 \mathrm{~g}$ of $p$-NFL in $1 \mathrm{~mL}$ of DMSO and diluted 100 times in a phosphate buffer solution $\mathrm{KH}_{2} \mathrm{PO}_{4} / \mathrm{K}_{2} \mathrm{HPO}_{4}(50 \mathrm{mM}$ and $\mathrm{pH}$ 7.0). The substrate solution was incubated at $37{ }^{\circ} \mathrm{C}$ for $30 \mathrm{~min} .200 \mu \mathrm{L}$ of each sample was added into $2.8 \mathrm{~mL}$ of substrate solution and the linear range of absorbance variation at $410 \mathrm{~nm}$ during $150 \mathrm{~s}\left(\Delta \mathrm{Abs} \cdot \mathrm{min}^{-1}\right)$ was analysed. The enzyme activity is expressed in $U \cdot L^{-1}$, being one unit $(U)$ of enzyme activity defined as the amount of enzyme that produces $1 \mu \mathrm{mol}$ of $p$-NP per minute under standard assay conditions.

\section{Protein assay}

The protein concentration was determined by the Bradford's method, ${ }^{42}$ using a UV-Vis spectrophotometer (Shimadzu, UV-1800) at $595 \mathrm{~nm}$, and a standard calibration curve established using the standard protein BSA. To eliminate the influence of the ILs presence on the protein concentration analysis, a blank control system for each partition systems without enzyme was prepared under the same conditions used as reference for measurement.

\section{Sodium dodecylsulfate-polyacrylamide gel electrophoresis (SDS-PAGE) analysis}

The SDS-PAGE analysis was performed using hand cast polyacrylamide gel made of a $12 \%$ revolving gel and a $4 \%$ stacking gel, thus added to a vertical gel electrophoresis unit (Bio-Rad, model mini-PROTEAN tetra cell), as described by Laemmli, ${ }^{43}$ at $160 \mathrm{~V}$ for 1 hour. After the electrophoresis process, the gel was stained following the direct silver staining procedure. 


\section{Results and discussion}

\section{Synthesis and characterization of GB-ILs}

The chemical structures of the synthesized GB-ILs depicted in Figure S1 in SI, were confirmed by NMR analysis as reported in Table S1 in SI. Unlike the previous work, ${ }^{32}$ all the GB-ILs in this study are liquids at room temperature, except [ $\left.\mathrm{N}_{4,4,4,4}\right][\mathrm{TAPSO}$, $\left[\mathrm{P}_{4,4,4,4}\right][\mathrm{TAPSO}]$ and $[\mathrm{Ch}][\mathrm{CAPSO}]$.

All GB-ILs studied are completely miscible with water. The potential of aqueous solutions of GB-ILs to act as a buffer media was investigated by determining their $\mathrm{pH}$ profiles, which corresponds to the titration of acid and base, at $25^{\circ} \mathrm{C}$ and $37^{\circ} \mathrm{C}$. All the buffering properties data of GB-ILs and GBs are presented in Table S2 of the SI. As depicted in Figure 1(a), GBILs with the same anionic species have identical buffering capacity at every single acid/base titration points as the respective GB, including their buffer region, midpoint of buffer region and buffer capacity.

One of the important characteristics of the GBs is the temperature stability of their buffering capacity. This temperature independent character of the buffering ability is also displayed by GB-ILs, for which there is only a slight change in their buffering behaviour between $25^{\circ} \mathrm{C}$ and $37^{\circ} \mathrm{C}$, as depicted in Figure 1(b) for the GB-ILs based on the MOPSO anion. This GB-ILs behaviour shows their potential as buffer media to be used at the optimum temperature of a specific enzyme.

The (eco)toxicity of each GB-IL for 5, 15 and 30 minutes of exposure was assessed using Microtox bioassay and further compared with the respective GBs toxicity $\left(\mathrm{EC}_{50}\right.$ data in unit of $\mathrm{mg} \cdot \mathrm{L}^{-1}$ and $\mathrm{mmol} \cdot \mathrm{L}^{-1}$, respectively, in Table S3 and Table S4 in SI). In general, GBs demonstrate a toxicity decrease with the increase of exposure time from 5 to 30 minutes, which is explained by the marine bacteria adaptation to the solution. An inverse trend of toxicity-exposure time relationship was observed for tetrabutylammonium- and 
tetrabutylphosphonium-based GB-ILs, exhibiting at the same time, an increase of toxicity with exposure time, which is justified by the fact that longer time periods of contact are essential for the toxicity mechanism to take place. ${ }^{44-45}$ On the other hand, cholinium-based GB-ILs show a nonlinear relationship of toxicity-exposure time and this complexity might be explained by the different trends found for this family ${ }^{44}$ and also probably due to the toxicity mechanism in which both cationic and anionic parts participate.

To carry the analysis at the maximum effect of the GB-ILs towards the bacteria, the discussion will be based on the 30-minutes of exposure time (Figure 2). Taking into account the $30 \mathrm{~min}-\mathrm{EC}_{50}>100 \mathrm{mg} \cdot \mathrm{L}^{-1}$ obtained, all GB-ILs studied can be classified as "practically harmless". ${ }^{44}$ The results here reported suggest that the cation has a dominant impact on the GB-ILs ecotoxicity, following an increasing tendency of $[\mathrm{Ch}]^{+}<\left[\mathrm{N}_{4,4,4,4}\right]^{+}<\left[\mathrm{P}_{4,4,4,4}\right]^{+}$. It is noteworthy to mention that the incorporation of the cholinium into the structure of GBs contributes, in this case, to drastically reduce the toxicity of the salts while simultaneously magnifying the effect of the anions, following the identical trend of increasing ecotoxicity exhibited by their respective GBs in the order: $[\mathrm{CAPSO}]^{-}<[\mathrm{BES}]^{-}<[\mathrm{MOPSO}]^{-}<$TAPSO $^{-}$. These results are consistent with the model prediction conducted by Couling et al ${ }^{46}$ where ILs toxicity decreases as the number of negatively charged atoms in the cation increases, and further strengthened by the experimental work stating that the cholinium cation (with negatively charged oxygen atoms) is relatively non-toxic. In addition, several works also reported that the toxicity increases with the elongation of the cation's alkyl side chain ${ }^{47-48}$ and this is supported by the findings that hydrophobic compounds will attach or penetrate into membranes of aquatic organisms, resulting in the disruption of their metabolic activity. ${ }^{49}$ Besides, the results suggest that the phosphonium salts were shown to have a more deleterious effect on the bacterial population compared to the ammonium counterpart, which is in good agreement with our earlier work. ${ }^{48}$ 
In contrast to the least toxic cholinium-based GB-ILs, the variation of the anionic species has a minimal effect on the toxicity of the GB-ILs comprised of $\left[\mathrm{N}_{4,4,4,4}\right]^{+}$and $\left[\mathrm{P}_{4,4,4,4}\right]^{+}$ cations, which suggests that, for these particular GB-ILs, the toxicity is largely driven by the cation instead of the anion. In addition, those GB-ILs have different toxicity mechanisms since they do not follow the same ecotoxicity sequence of the respective GBs, described by the following trend: $[\mathrm{MOPSO}]^{-}<[\mathrm{BES}]^{-}<$TAPSO $^{-}<$[CAPSO $^{-}$. Likewise, when compared to those reported earlier, ${ }^{32}$ for the GB-ILs with the same cation, the presence of the betahydroxyl group in the anionic species of these GB-ILs in particular [MOPSO]', [TAPSO] ${ }^{-}$and [CAPSO $^{-}$contributes to a higher toxicity, although this functional group exerts a decreasing effect on the GBs' toxicity.

\section{Lipase enzyme activity in GB-ILs}

In the applications dealing with labile enzymes it is important that the enzyme-solvent system is capable to establish balanced interactions allowing the enzyme to retain its function and conformational structure. ${ }^{50}$ Phosphate buffer is commonly used in enzyme applications to keep the system's pH constant, preventing the alteration/disruption of the enzyme's surface properties. Moreover, the selection of the salting-out agent in IL-based ABS is limited by its effect on $\mathrm{pH}$, and thus, often a phosphate buffer aiming at controlling the $\mathrm{pH}$ value of the coexisting aqueous phases is used. ${ }^{19,51}$ Therefore, in order to examine the viability of selfbuffering GB-ILs as media for enzyme applications, the enzyme activity and stability parameters were investigated regarding the contact effect of $0.05 \mathrm{M}$ and $1.0 \mathrm{M}$ of water-GBILs mixtures $(\mathrm{pH}=7.0)$ after 4 hours of exposure, and the results were expressed in relative enzyme activity. Phosphate buffer in the same concentrations is used as control. The effects in water-GBs mixtures to enzyme were also studied. In this work, a lipase from P. cepacia was used as model enzyme. The class of lipases is widely recognized as a key enzyme as 
biocatalyst in biotechnological applications due to its multiplicity of catalytic applications. ${ }^{41,}$ $52-53$

As depicted in Figure 3(a), the lipase exhibits a higher activity after 4 hours of exposure to some of the $0.05 \mathrm{M}$ GB-ILs solutions, in particular GB-ILs based on the BES anion and [Ch][MOPSO], while a slightly lower relative activity was observed for the remaining GBILs, when compared with the results attained with the phosphate buffer. Besides, the lipase displays a lower relative activity after being in contact for 4 hours in both $0.05 \mathrm{M}$ and $1.0 \mathrm{M}$ of GBs' aqueous solution. This behaviour can be attributed to the kosmotropic/chaotropic effects, ${ }^{54}$ in which GBs comprising the sulfonate anion are more chaotropic than the phosphate anion and thus destabilize the enzyme. ${ }^{55}$ However, the incorporation of a bulky and hydrophobic cation into the GBs' structure has a significant effect in improving the enzyme-stabilizing properties of the GB-ILs. This effect is even more pronounced at high concentration of GB-ILs. At $1.0 \mathrm{M}$, tetrabutylammonium and tetrabutylphosphonium families demonstrate a higher capacity to enhance the enzyme's catalytic activity, with approximately (1.7 to 3.0)-fold higher activities when compared to phosphate buffer at the same concentration, as presented in Figure 3(b). These results clearly reveal that the enzyme activity is correlated with the hydrophilic/hydrophobic nature of the enzyme-solvent system on the water hydration level of micro-aqueous phase at the enzyme surface. ${ }^{56}$ The presence of tetrabutyl-ammonium and -phosphonium cations, comprising hydrophobic alkyl side chains, reduces the tendency to strip off the hydration water from the enzyme surface. On the other hand, cholinium-based GB-ILs with polar cations, especially at high concentrations, dehydrate the microenvironment at the enzyme surface causing enzyme deactivation. This behaviour explains the lower relative activity observed for the cholinium-based GB-ILs compared to their counterparts. The results here reported suggest that more hydrophobic GBILs stabilize the enzyme whereas hydrophilic GB-ILs act as an enzyme destabilizer as 
reported previously for other ILs. ${ }^{57}$ Additionally, the experimental results ascertain that tetrabutylammonium- and tetrabutylphosphonium-based GB-ILs contribute to the preservation of the enzyme active catalytic conformation in aqueous solution through balanced IL-enzyme interactions. Furthermore, the outstanding solvation ability normally found in ILs can enhance enzyme solubility and establish a better enzyme-medium-substrate relationship, ${ }^{15}$ and thus improve the enzymes catalytic efficiency.

\section{GB-IL based ABS}

The ability of GB-ILs to create ABS with biodegradable potassium citrate was investigated in order to assess the potential of the GB-ILs to create more efficient and sustainable ILsbased ABS. The experimental weight fraction data for the studied systems are provided in the SI (Table S5). The experimental binodal data of these systems was adequately fitted to the mathematical model described by eq. 2 . The corresponding parameters and the respective standard deviations and correlations are presented in the SI (Table S6). The general results of the ABS formation depicted in Figure 4 show that, apart from the cholinium-based GB-ILs, all the tetrabutylammonium- and tetrabutylphosphonium-based GB-ILs are able to undergo liquid-liquid demixing in presence of potassium citrate. The GB-ILs' ability to form ABS with potassium citrate follows the rank: $\left[\mathrm{N}_{4,4,4,4}\right][$ TAPSO $]<\left[\mathrm{P}_{4,4,4,4}\right][$ TAPSO $]<$ $\left[\mathrm{N}_{4,4,4,4}\right][\mathrm{BES}]<\left[\mathrm{N}_{4,4,4,4}\right][\mathrm{MOPSO}]<\left[\mathrm{P}_{4,4,4,4}\right][\mathrm{BES}]<\left[\mathrm{P}_{4,4,4,4}\right][\mathrm{MOPSO}]<\left[\mathrm{N}_{4,4,4,4}\right][\mathrm{CAPSO}]$ $<\left[\mathrm{P}_{4,4,4,4}\right][\mathrm{CAPSO}]$. The ability of quaternary ammonium and phosphonium salts for ABS formation can be attributed to their higher hydrophobicity resulting from the four butyl side chains attached to the central heteroatom, leading to a low affinity for water and, consequently, displaying a higher tendency to be salted-out from the aqueous solution. Quaternary salts with phosphorus as the cation's central atom have demonstrated a higher hydrophobic nature when compared to ammonium salts ${ }^{48}$ and thus are more effective in promoting the ABS formation. ${ }^{26}$ Cholinium cations, which are smaller in size and present a 
polar hydroxyl group at the side chain, have a higher affinity for water which reduces their ability to induce ABS formation with citrates. Nevertheless, cholinium-based GB-ILs are capable to form ABS with more hydrophobic phase components. ${ }^{31,33}$

The influence of the ILs anion's nature on the ABS formation is also dominated by the system hydrophobicity/hydrophilicity ${ }^{39}$. Thereby, the GB-ILs aptitude to induce ABS, for the same cation, follows the anions hydrophobic sequence: $\left[\mathrm{TAPSO}^{-}<[\mathrm{BES}]^{-}<\mathrm{MOPSO}^{-}<\right.$ [CAPSO]', reflected by the octanol-water partition coefficient: TAPSO $(\log \mathrm{P}=-2.81)<$ BES $(\log \mathrm{P}=-2.52)<$ MOPSO $(\log \mathrm{P}=-2.05)<\mathrm{CAPSO}(\log \mathrm{P}=-0.36) .{ }^{58}$ Additionally, the effect of the anion's nature on ABS phase behaviour is correlated with the relative hydrogen bond accepting strength of the IL's anion. ${ }^{59}$ The anionic species with greater hydrogen bond accepting strength, in this case [TAPSO]', present larger ability to form stronger interactions with water and to create hydration complexes, and therefore they are not easily salted-out (for more details see Table S7 of the SI).

\section{Partitioning studies of lipase from $P$. cepacia in GB-ILs based ABS}

The applicability of GB-ILs based ABS in purification system dealing with labile enzymes was evaluated through the determination of the partitioning of lipase from P. cepacia in GBILs-based ABS. Several GB-ILs-based ABS were selected considering their buffering capacity at $\mathrm{pH}$ 7.0. For all the six selected GB-ILs/potassium citrate ABS, the biphasic mixture chosen for the lipase partitioning corresponds to the TLs with similar TLL, namely between 40.23 and 42.65 , in order to guarantee identical compositions of each component and similar surrounding environment conditions for the enzyme partition. The shorter tie-line was chosen as the operation biphasic mixture for the partitioning studies to minimize the difference in physical properties between the two phases and maximize the water content, providing a gentle environment for the enzyme. All the ternary phase diagrams for the selected ABS composed by GB-ILs with the TLs determined and the respective operation 
two-phase point are presented in SI (Figure S2). It should be highlighted that for all ABS studied, the top layer is the GB-IL-rich phase, whereas the bottom represents the salt-rich phase. As aforementioned, a commercial lipase from $P$. cepacia was applied as a model enzyme and the respective SDS-PAGE analysis is reported in SI (Figure S3). It is clearly seen the presence of the target lipase from P. cepacia at circa $33 \mathrm{kDa}$, which is consistent with the literature, ${ }^{60}$ and several less pronounced bands representing the contaminant proteins. Since the lipase used in this study is of commercial purity, the expectable purification in the GB-ILs-based ABS is limited.

Table 1 presents the phase compositions of GB-IL/potassium citrate ABS, the respective TLL, partition coefficients and recovery yields of both enzyme and total proteins, and as well as the purification factors and selectivity parameters. In all the investigated systems, the lipolytic enzyme partitions preferentially to the GB-IL-rich (top) phase. The enzyme displays partition coefficients, between $29.3 \pm 1.9$ and $119.5 \pm 7.0$, while the enzyme recovery yields at the GB-IL-rich phase ranges from $95.7 \pm 0.3(\%)$ to $99.2 \pm 0.0(\%)$. The total protein recovery yields achieved at the GB-IL-rich phase range between $93.4 \pm 0.7(\%)$ and $97.1 \pm$ $0.1(\%)$, based on the partition coefficients ranging from $18.3 \pm 0.6$ to $36.9 \pm 1.6$. The results for enzyme and total proteins recovery yields at the GB-IL-rich (top) phase are similar, since almost all the lipolytic enzyme (protein exhibiting lipolytic activity) migrates to the top phase. As described before, the main goal of using ABS based in the GB-ILs was the evaluation of their potential as purification systems, meaning their capacity to isolate the target enzyme from the remaining proteins (here considered as the contaminants present in the system). As the protein partitioning in ABS can be described as a surface-dependent phenomenon, ${ }^{61}$ it can be proposed that the preferential partition of lipolytic enzyme into GBIL-rich phase is mainly due to the hydrophobic interaction with the hydrophobic groups of GB-ILs. Furthermore, bigger proteins with negative charges on their surface will tend to have 
higher affinity to the IL-rich phase, mainly because of the driving force established by the interactions between negatively charged amino-acid residues and the IL's cation. ${ }^{15}$ Thus, the extent of the enzyme isolation from the contaminant proteins is here discussed by considering the $\mathrm{S}_{\mathrm{E} / \mathrm{P}}$ presented in Table 1 .

The results obtained demonstrate that all of these systems, especially those based on the BES anion, in particular $\left[\mathrm{N}_{4,4,4,4}\right][\mathrm{BES}]$ and $\left[\mathrm{P}_{4,4,4,4}\right][\mathrm{BES}]$, are more selective to the target enzyme than to total proteins, thus showing a selective capacity to isolate the target lipase from the main contaminants. It should be highlighted that, despite the limited selectivity parameters observed in this study, these results suggest that, with the adequate optimization of different conditions, it will be possible to increase the purification capacity of these ABS. In this context, this work proposes the development of an integrated process scheme considering the industrialization of this process, combining the self-buffering and enzymestabilizing properties of the GB-ILs as media of the catalytic reaction step. In this process, the advantages of GB-ILs as extraction solvents in ABS, thus allowing the enzyme recycling and the products purification is envisaged, as depicted in Figure 5. This process will allow the recovery of most of the GB-ILs, since the recyclability of the top layer, enriched in GB-ILs is possible to be totally achieved, which will be decreasing the economic impact and environmental footprint of the process. ${ }^{62}$ 


\section{Conclusions}

GB-ILs were synthesized with anions derived from Good's buffers (MOPSO, BES, TAPSO, and CAPSO) and coupled with tetrabutylammonium, tetrabutylphosphonium and cholinium cations. It was shown that these "practically harmless" GB-ILs possess temperature independent self-buffering characteristics and exhibit an enzyme-stabilizing effect for retaining the catalytic activity of lipase from P. cepacia. Besides, these GB-ILs are capable to form ABS with a biodegradable citrate salt and present a significant selectivity on the isolation of the target lipolytic enzyme from $P$. cepacia into GB-ILs ascertaining the potential of these GB-ILs-based ABS as purification technologies. The ABS technique based on GB-ILs can be a feasible alternative to replace the conventional ABS using phosphate buffer for the extraction of the biomolecules in particular enzymes. The experimental data reported suggest that GB-ILs should be further explored for their application in enzyme catalysis and/or bioseparation technology, due to their great advantageous properties. 


\section{Acknowledgements}

The authors gratefully acknowledge the financial support from the Ministry of Science, Technology and Innovation, Malaysia, through Grant No. 02-02-12-SF0256 and MyBrain 15 Scholarship from the Ministry of Higher Education (MOHE), Malaysia of L.S.Y. The authors are grateful for the financial support from FEDER funds through the program COMPETE and for national fund through the Portuguese Foundation for Science and Technology (FCT) for CICECO-Aveiro Institute of Materials Ref. FCT UID/CTM/50011/2013, the research project PTDC/ATP-EAM/5331/2014, the doctoral grants of SFRH/BD/94901/2013, SFRH/BD/85871/2012, SFRH/BD/101683/2014 of A.F. e Silva, T.E. Sintra, F.A. Vicente, and the post-doctoral grant SFRH/BPD/79263/2011 of S.P.M. Ventura.

\section{Supporting Information}

Experimental details for GB-ILs synthesis and characterization, NMR analysis of GB-ILs, buffering properties data of GB-ILs/GBs, $\mathrm{EC}_{50}-5,15$, and $30 \mathrm{~min}$ data of $\mathrm{GB}-\mathrm{ILs} / \mathrm{GBs}$, experimental weight fraction data for GB-ILs-based ABS, the correlation constants by the regression of the experimental binodal data through the application of eq. 2 of the studied systems, H-bond formation tendency of GB-ILs anions, chemical structures, full names and acronyms of the synthesized GB-ILs, ternary phase diagrams for the selected systems for enzyme partition study and SDS-PAGE patterns of commercial lipase from $P$. cepacia. The Supporting Information is available free of charge on the website. 


\section{References}

1. Mallakpour, S.; Rafiee, Z. Ionic Liquids as Environmentally Friendly Solvents in Macromolecules Chemistry and Technology, Part I. J. Polym. Environ. 2011, 19 (2), 447-484.

2. Zhang, S.; Sun, N.; He, X.; Lu, X.; Zhang, X. Physical properties of ionic liquids: database and evaluation. J. Phys. Chem. Ref. Data 2006, 35 (4), 1475-1517.

3. Plechkova, N. V.; Seddon, K. R. Applications of ionic liquids in the chemical industry. Chem. Soc. Rev. 2008, 37 (1), 123-150.

4. Moniruzzaman, M.; Nakashima, K.; Kamiya, N.; Goto, M. Recent advances of enzymatic reactions in ionic liquids. Biochem. Eng. J. 2010, 48 (3), 295-314.

5. Kragl, U.; Eckstein, M.; Kaftzik, N. Enzyme catalysis in ionic liquids. Curr. Opin. Biotechnol. 2002, $13(6), 565-571$.

6. Sheldon, R. A.; Lau, R. M.; Sorgedrager, M. J.; van Rantwijk, F.; Seddon, K. R. Biocatalysis in ionic liquids. Green Chem. 2002, 4 (2), 147-151.

7. Lozano, P. Enzymes in neoteric solvents: From one-phase to multiphase systems. Green Chem. 2010, 12 (4), 555-569.

8. Potdar, M. K.; Kelso, G. F.; Schwarz, L.; Zhang, C.; Hearn, M. T. Recent Developments in Chemical Synthesis with Biocatalysts in Ionic Liquids. Molecules 2015, 20 (9), 16788-16816.

9. Oppermann, S.; Stein, F.; Kragl, U. Ionic liquids for two-phase systems and their application for purification, extraction and biocatalysis. Appl. Microbiol. Biotechnol. 2011, $89(3), 493-499$. 
10. Li, Z.; Pei, Y.; Wang, H.; Fan, J.; Wang, J. Ionic liquid-based aqueous two-phase systems and their applications in green separation processes. TrAC, Trends Anal. Chem. 2010, 29 (11), 1336-1346.

11. Ha, S. H.; Hiep, N. M.; Koo, Y.-M. Enhanced production of fructose palmitate by lipase-catalyzed esterification in ionic liquids. Biotechnol. Bioprocess Eng. 2010, 15 (1), $126-130$.

12. Ulbert, O.; Fráter, T.; Bélafi-Bakó, K.; Gubicza, L. Enhanced enantioselectivity of Candida rugosa lipase in ionic liquids as compared to organic solvents. J. Mol. Catal. B: Enzym. 2004, 31 (1), 39-45.

13. Munoz, P. A.; Correa-Llanten, D. N.; Blamey, J. M. Ionic liquids increase the catalytic efficiency of a lipase (Lip1) from an antarctic thermophilic bacterium. Lipids 2015, $50(1), 49-55$.

14. Pereira, J. F. B.; Ventura, S. P. M.; e Silva, F. A.; Shahriari, S.; Freire, M. G.; Coutinho, J. A. P. Aqueous biphasic systems composed of ionic liquids and polymers: A platform for the purification of biomolecules. Sep. Purif. Technol. 2013, 113, 83-89.

15. Dreyer, S.; Kragl, U. Ionic liquids for aqueous two-phase extraction and stabilization of enzymes. Biotechnol. Bioeng. 2008, 99 (6), 1416-1424.

16. Dreyer, S.; Salim, P.; Kragl, U. Driving forces of protein partitioning in an ionic liquid-based aqueous two-phase system. Biochem. Eng. J. 2009, 46 (2), 176-185.

17. Ng, H. S.; Ooi, C. W.; Show, P. L.; Tan, C. P.; Ariff, A.; Moktar, M. N.; Ng, E.-P.; Ling, T. C. Recovery of Bacillus cereus cyclodextrin glycosyltransferase using ionic liquidbased aqueous two-phase system. Sep. Purif. Technol. 2014, 138, 28-33.

18. Cao, Q.; Quan, L.; He, C.; Li, N.; Li, K.; Liu, F. Partition of horseradish peroxidase with maintained activity in aqueous biphasic system based on ionic liquid. Talanta 2008, 77 (1), 160-165. 
19. Ventura, S. P. M.; de Barros, R. L. F.; de Pinho Barbosa, J. M.; Soares, C. M. F.; Lima, Á. S.; Coutinho, J. A. P. Production and purification of an extracellular lipolytic enzyme using ionic liquid-based aqueous two-phase systems. Green Chem. 2012, 14 (3), $734-740$.

20. Ventura, S. P.; Sousa, S. G.; Freire, M. G.; Serafim, L. S.; Lima, A. S.; Coutinho, J. A. Design of ionic liquids for lipase purification. J. Chromatogr. B 2011, 879 (26), 2679-2687.

21. Deive, F. J.; Rodríguez, A.; Rebelo, L. P. N.; Marrucho, I. M. Extraction of Candida antarctica lipase A from aqueous solutions using imidazolium-based ionic liquids. Sep. Purif. Technol. 2012, 97, 205-210.

22. Deive, F. J.; Rodríguez, A.; Pereiro, A. B.; Araújo, J. M. M.; Longo, M. A.; Coelho, M. A. Z.; Lopes, J. N. C.; Esperança, J. M. S. S.; Rebelo, L. P. N.; Marrucho, I. M. Ionic liquid-based aqueous biphasic system for lipase extraction. Green Chem. 2011, 13 (2), 390-396.

23. Good, N. E.; Izawa, S. Hydrogen ion buffers. Methods Enzymol. 1972, 24, 53-68.

24. Stoll, V. S.; Blanchard, J. S. Buffers: principles and practice. Methods Enzymol. 1989, $182,24-38$.

25. Macfarlane, D. R.; Vijayaraghavan, R.; Ha, H. N.; Izgorodin, A.; Weaver, K. D.; Elliott, G. D. Ionic liquid "buffers"-pH control in ionic liquid systems. Chem. Commun. 2010, 46 (41), 7703-7705.

26. Sintra, T. E.; Cruz, R.; Ventura, S. P. M.; Coutinho, J. A. P. Phase diagrams of ionic liquids-based aqueous biphasic systems as a platform for extraction processes. J. Chem. Thermodyn. 2014, 77, 206-213. 
27. Passos, H.; Ferreira, A. R.; Cláudio, A. F. M.; Coutinho, J. A. P.; Freire, M. G. Characterization of aqueous biphasic systems composed of ionic liquids and a citrate-based biodegradable salt. Biochem. Eng. J. 2012, 67, 68-76.

28. Zafarani-Moattar, M. T.; Hamzehzadeh, S. Effect of $\mathrm{pH}$ on the phase separation in the ternary aqueous system containing the hydrophilic ionic liquid 1-butyl-3-methylimidazolium bromide and the kosmotropic salt potassium citrate at $\mathrm{T}=298.15 \mathrm{~K}$. Fluid Phase Equilib. 2011, 304 (1), 110-120.

29. Mohammad, A. Green solvents II: properties and applications of ionic liquids. Springer Netherlands, 2012; Vol. 2, p 506.

30. Ou, G.-n.; Zhu, M.-x.; She, J.-r.; Yuan, Y.-z. Ionic liquid buffers: a new class of chemicals with potential for controlling $\mathrm{pH}$ in non-aqueous media. Chem. Commun. 2006, (44), 4626-4628.

31. Taha, M.; Quental, M. V.; Correia, I.; Freire, M. G.; Coutinho, J. A. P. Extraction and stability of bovine serum albumin (BSA) using cholinium-based Good's buffers ionic liquids. Process Biochem. 2015, 50 (7), 1158-1166.

32. Taha, M.; FA, E. S.; Quental, M. V.; Ventura, S. P.; Freire, M. G.; Coutinho, J. A. Good's buffers as a basis for developing self-buffering and biocompatible ionic liquids for biological research. Green Chem. 2014, 16 (6), 3149-3159.

33. Taha, M.; Almeida, M. R.; Silva, F. A.; Domingues, P.; Ventura, S. P.; Coutinho, J. A.; Freire, M. G. Novel biocompatible and self-buffering ionic liquids for biopharmaceutical applications. Chem. Eur. J. 2015, 21 (12), 4781-4788.

34. Good, N. E.; Winget, G. D.; Winter, W.; Connolly, T. N.; Izawa, S.; Singh, R. M. M. Hydrogen Ion Buffers for Biological Research*. Biochemistry 1966, 5 (2), 467-477. 
35. Pereira, M. M.; Pedro, S. N.; Quental, M. V.; Lima, A. S.; Coutinho, J. A.; Freire, M. G. Enhanced extraction of bovine serum albumin with aqueous biphasic systems of phosphonium- and ammonium-based ionic liquids. J. Biotechnol. 2015, 206, 17-25.

36. Shahriari, S.; Tomé, L. C.; Araújo, J. M. M.; Rebelo, L. P. N.; Coutinho, J. A. P.; Marrucho, I. M.; Freire, M. G. Aqueous biphasic systems: a benign route using choliniumbased ionic liquids. RSC Advances 2013, 3 (6), 1835-1843.

37. Quental, M. V.; Caban, M.; Pereira, M. M.; Stepnowski, P.; Coutinho, J. A.; Freire, M. G. Enhanced extraction of proteins using cholinium-based ionic liquids as phase-forming components of aqueous biphasic systems. Biotechnol. J. 2015, 10 (9), 1457-1466.

38. Ventura, S. P.; Marques, C. S.; Rosatella, A. A.; Afonso, C. A.; Goncalves, F.; Coutinho, J. A. Toxicity assessment of various ionic liquid families towards Vibrio fischeri marine bacteria. Ecotoxicol. Environ. Saf. 2012, 76 (2), 162-168.

39. Freire, M. G.; Claudio, A. F.; Araujo, J. M.; Coutinho, J. A.; Marrucho, I. M.; Canongia Lopes, J. N.; Rebelo, L. P. Aqueous biphasic systems: a boost brought about by using ionic liquids. Chem. Soc. Rev. 2012, 41 (14), 4966-4995.

40. Ventura, S. P. M.; Sousa, S. G.; Serafim, L. S.; Lima, Á. S.; Freire, M. G.; Coutinho, J. A. P. Ionic-Liquid-Based Aqueous Biphasic Systems with Controlled pH: The Ionic Liquid Anion Effect. J. Chem. Eng. Data 2012, 57 (2), 507-512.

41. Ventura, S. P.; Santos, L. D.; Saraiva, J. A.; Coutinho, J. A. Concentration effect of hydrophilic ionic liquids on the enzymatic activity of Candida antarctica lipase B. World $J$. Microbiol. Biotechnol. 2012, 28 (6), 2303-2310.

42. Bradford, M. M. A rapid and sensitive method for the quantitation of microgram quantities of protein utilizing the principle of protein-dye binding. Anal. Biochem. 1976, 72 (1), 248-254. 
43. Laemmli, U. K. Cleavage of structural proteins during the assembly of the head of bacteriophage T4. Nature 1970, 227 (5259), 680-685.

44. Ventura, S. P.; e Silva, F. A.; Goncalves, A. M.; Pereira, J. L.; Goncalves, F.; Coutinho, J. A. Ecotoxicity analysis of cholinium-based ionic liquids to Vibrio fischeri marine bacteria. Ecotoxicol. Environ. Saf. 2014, 102, 48-54.

45. Santos, J. I.; Gonçalves, A. M.; Pereira, J.; Figueiredo, B.; e Silva, F.; Coutinho, J. A.; Ventura, S. P.; Gonçalves, F. Environmental safety of cholinium-based ionic liquids: assessing structure-ecotoxicity relationships. Green Chem. 2015, 17 (9), 4657-4668.

46. Couling, D. J.; Bernot, R. J.; Docherty, K. M.; Dixon, J. K.; Maginn, E. J. Assessing the factors responsible for ionic liquid toxicity to aquatic organisms via quantitative structure-property relationship modeling. Green Chem. 2006, 8 (1), 82-90.

47. Stolte, S.; Matzke, M.; Arning, J.; Böschen, A.; Pitner, W.-R.; Welz-Biermann, U.; Jastorff, B.; Ranke, J. Effects of different head groups and functionalised side chains on the aquatic toxicity of ionic liquids. Green Chem. 2007, 9 (11), 1170-1179.

48. Carvalho, P. J.; Ventura, S. P.; Batista, M. L.; Schroder, B.; Goncalves, F.; Esperanca, J.; Mutelet, F.; Coutinho, J. A. Understanding the impact of the central atom on the ionic liquid behavior: phosphonium vs ammonium cations. J. Chem. Phys. 2014, 140 (6), 064505.

49. Escher, B. I.; Schwarzenbach, R. P. Mechanistic studies on baseline toxicity and uncoupling of organic compounds as a basis for modeling effective membrane concentrations in aquatic organisms. Aquat. Sci. 2002, 64 (1), 20-35.

50. Ou, G.; He, B.; Yuan, Y. Lipases are soluble and active in glycerol carbonate as a novel biosolvent. Enzyme Microb. Technol. 2011, 49 (2), 167-170.

51. Souza, R. L.; Lima, R. A.; Coutinho, J. A. P.; Soares, C. M. F.; Lima, Á. S. Novel aqueous two-phase systems based on tetrahydrofuran and potassium phosphate buffer for purification of lipase. Process Biochem. 2015, 50 (9), 1459-1467. 
52. Ventura, S. P.; Santos, L. D.; Saraiva, J. A.; Coutinho, J. A. Ionic liquids microemulsions: the key to Candida antarctica lipase B superactivity. Green Chem. 2012, 14 (6), 1620-1625.

53. Gupta, R.; Gupta, N.; Rathi, P. Bacterial lipases: an overview of production, purification and biochemical properties. Appl. Microbiol. Biotechnol. 2004, 64 (6), 763-781.

54. Ugwu, S. O.; Apte, S. P. The effect of buffers on protein conformational stability. Pharm. Technol. 2004, 28 (3), 86-109.

55. Wu, C. F.; Cha, H. J.; Valdes, J. J.; Bentley, W. E. GFP-visualized immobilized enzymes: Degradation of paraoxon via organophosphorus hydrolase in a packed column. Biotechnol. Bioeng. 2002, 77 (2), 212-218.

56. Laszlo, J. A.; Compton, D. L. $\alpha$-Chymotrypsin catalysis in imidazolium-based ionic liquids. Biotechnol. Bioeng. 2001, 75 (2), 181-186.

57. Hernández-Fernández, F.; De los Rios, A.; Tomás-Alonso, F.; Gomez, D.; Víllora, G. Stability of hydrolase enzymes in ionic liquids. Can. J. Chem. Eng. 2009, 87 (6), 910-914.

58. ChemSpider. http://www.chemsipider.com/. (accessed June 10, 2015).

59. Ventura, S. P.; Neves, C. M.; Freire, M. G.; Marrucho, I. M.; Oliveira, J.; Coutinho, J. A. Evaluation of anion influence on the formation and extraction capacity of ionic-liquidbased aqueous biphasic systems. J. Phys. Chem. B 2009, 113 (27), 9304-9310.

60. Padilha, G. D. S.; Santana, J. C. C.; Alegre, R. M.; Tambourgi, E. B. Extraction of lipase from Burkholderia cepacia by PEG/Phosphate ATPS and its biochemical characterization. Braz Arch Biol Technol 2012, 55 (1), 7-19.

61. Albertsson, P. Å. Partition of cell particles and macromolecules. 3rd ed.; Wiley: New York, 1986; p 346. 
62. Alvarez-Guerra, E.; Irabien, A.; Ventura, S. P.; Coutinho, J. A. Ionic liquid recovery alternatives in ionic liquid-based three-phase partitioning (ILTPP). AICHE J. 2014, 60 (10), $3577-3586$. 
Table 1. Experimental results of the partition, purification and selectivity parameters of lipase from $P$. cepacia between both aqueous phases of GB-ILs-based ABS, and respective standard deviations, $\sigma$.

\begin{tabular}{|c|c|c|c|c|c|c|c|c|c|}
\hline GB-ILs & IL (wt \%) & $\begin{array}{l}\mathrm{K}_{3} \mathrm{C}_{6} \mathrm{H}_{5} \mathrm{O}_{7} \\
(\mathrm{wt} \%)\end{array}$ & TLL & $\mathbf{R}_{\mathbf{V}} \pm$ std & $\mathbf{K}_{\mathbf{E}} \pm \mathrm{std}$ & $\mathbf{R}_{\mathbf{T}}^{\mathbf{E}} \pm \operatorname{std}(\%)$ & $\mathbf{K}_{\mathbf{P}} \pm$ std & $\mathbf{R}_{\mathbf{T}}^{\mathbf{P}} \pm \operatorname{std}(\%)$ & $\mathrm{S}_{\mathrm{E} / \mathrm{P}}$ \\
\hline$\left[\mathrm{P}_{4,4,4,4}\right][\mathrm{MOPSO}]$ & 29.68 & 15.00 & 40.23 & $1.58 \pm 0.00$ & $29.3 \pm 1.9$ & $97.9 \pm 0.3$ & $18.3 \pm 0.6$ & $96.6 \pm 0.3$ & 1.60 \\
\hline$\left[\mathrm{N}_{4,4,4,4}\right][\mathrm{BES}]$ & 27.00 & 20.00 & 41.44 & $1.05 \pm 0.00$ & $115.7 \pm 6.0$ & $99.2 \pm 0.0$ & $32.4 \pm 0.9$ & $97.1 \pm 0.1$ & 3.57 \\
\hline$\left[\mathrm{N}_{4,4,4,4}\right][$ TAPSO $]$ & 31.69 & 20.00 & 41.08 & $0.93 \pm 0.03$ & $82.1 \pm 3.5$ & $98.7 \pm 0.1$ & $35.1 \pm 2.7$ & $97.0 \pm 0.2$ & 2.34 \\
\hline$\left[\mathrm{P}_{4,4,4,4}\right][$ TAPSO $]$ & 29.20 & 20.00 & 41.97 & $0.60 \pm 0.00$ & $41.7 \pm 3.0$ & $96.1 \pm 0.3$ & $23.6 \pm 2.8$ & $93.4 \pm 0.7$ & 1.77 \\
\hline
\end{tabular}


(a)

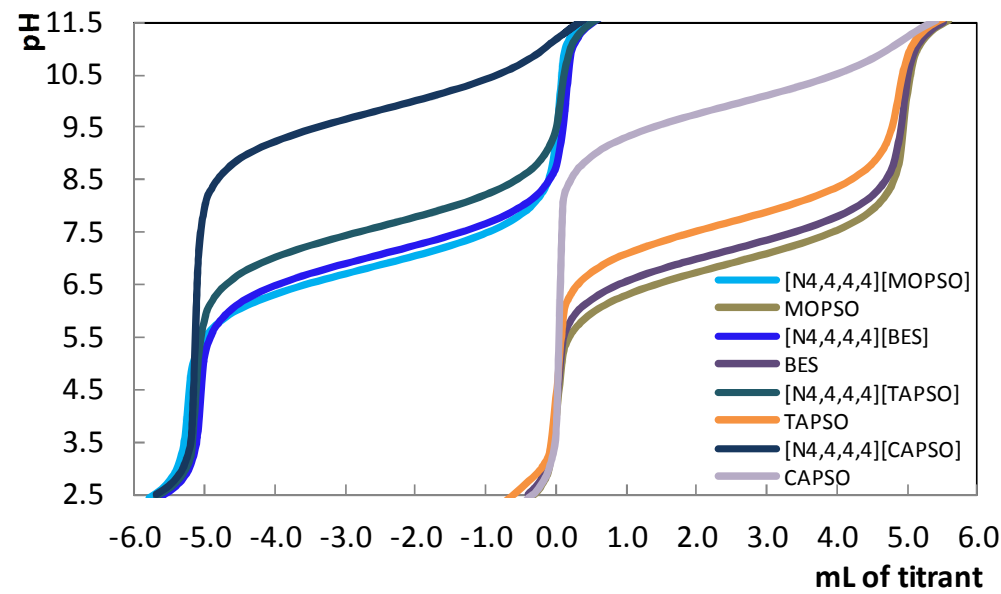

(b)

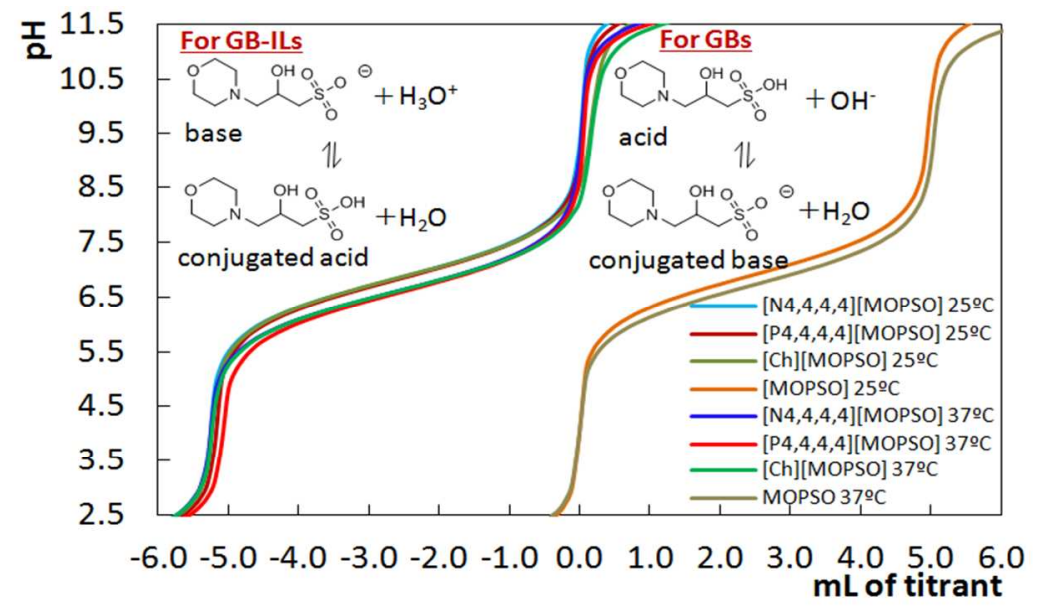

Figure 1. The $\mathrm{pH}$ acid-base titration profiles of (a) tetrabutylammonium-based GB-ILs and the GBs at $25{ }^{\circ} \mathrm{C}$; (b) GB-ILs based on the MOPSO anion and the respective GB, MOPSO, at $25{ }^{\circ} \mathrm{C}$ and $37^{\circ} \mathrm{C}$. The titrant volumes from $0-6 \mathrm{~mL}$ are for titration of the $0.05 \mathrm{M}$ GB-ILs/GBs aqueous solutions with $0.05 \mathrm{M} \mathrm{NaOH}$, whereas $-1 \mathrm{~mL}$ entries correspond to the volumes of $0.05 \mathrm{M} \mathrm{HCl}$ added into aqueous solution of GB-ILs/GBs (reverse titration). 


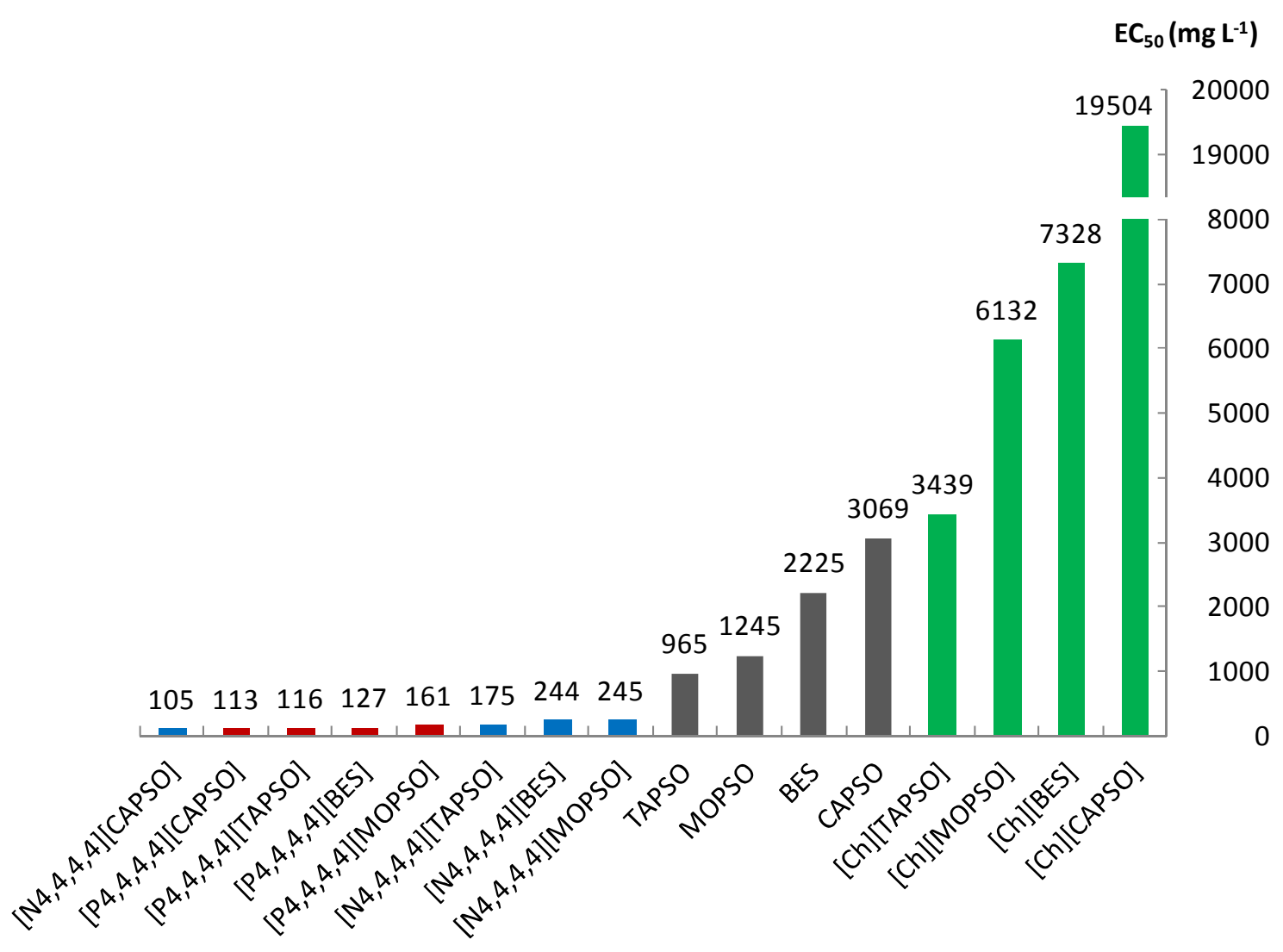

Figure 2. $\mathrm{EC}_{50}$ experimental values towards the bioluminescent marine bacteria, Vibrio fischeri, at $30 \mathrm{~min}$ of exposure time to cholinium-based GB-ILs (green bars), tetrabutylammonium-based GB-ILs (blue bars), tetrabutylphosphonium-based GB-ILs (red bars) and GBs (grey bars). 
(a)

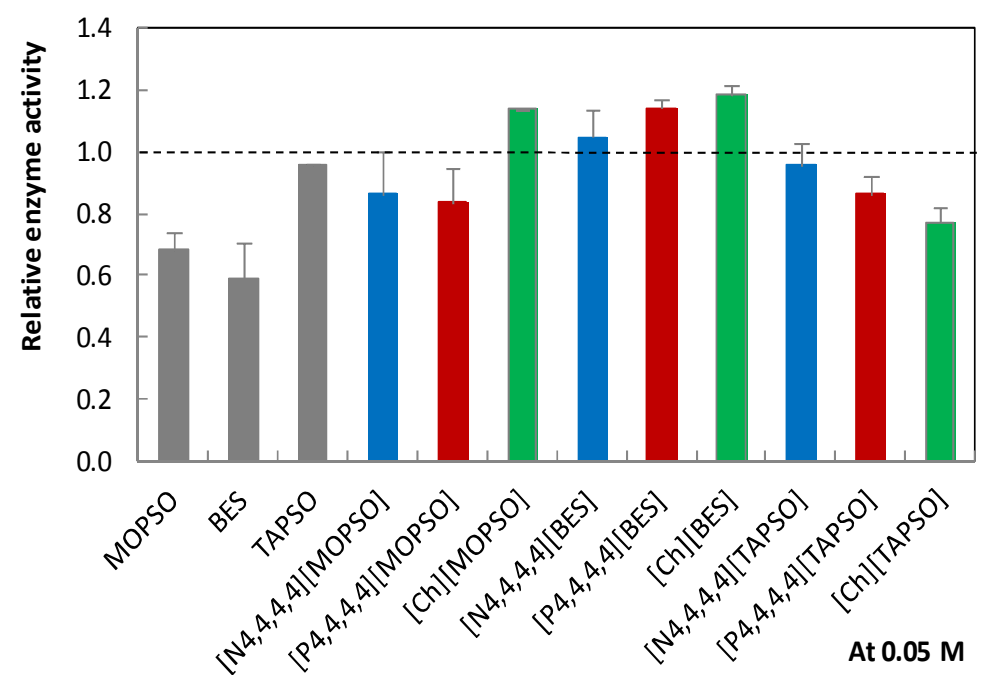

(b)

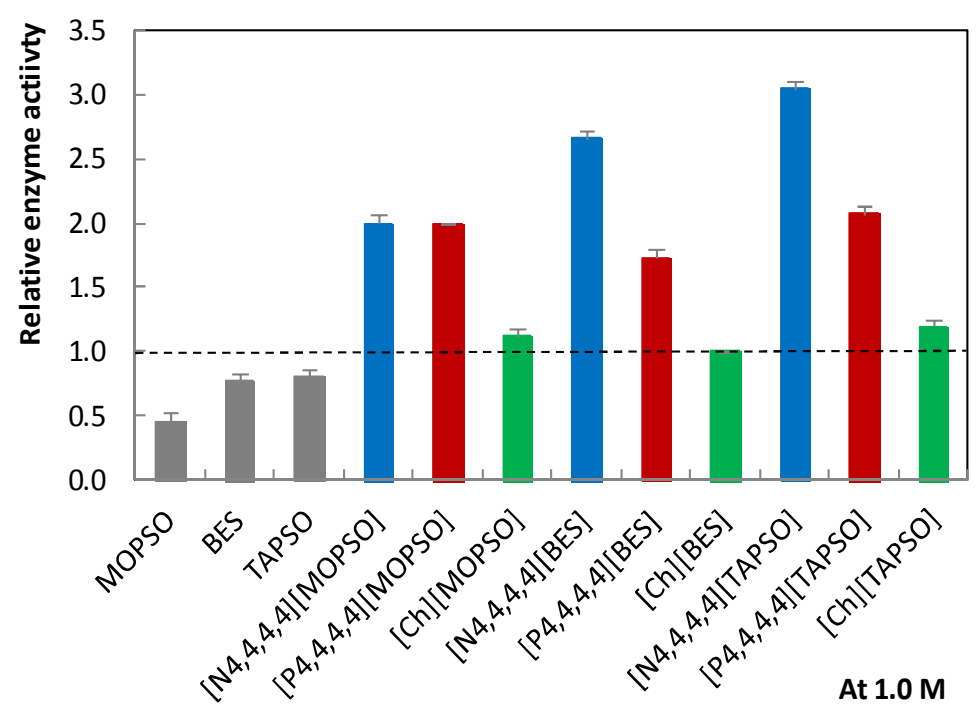

Figure 3. Relative enzyme activity of a lipase from $P$. cepacia after being in contact for 4 hours with (a) $0.05 \mathrm{M}$ and (b) $1.0 \mathrm{M}$ of aqueous solutions of cholinium-based GB-ILs (green bars), tetrabutylammonium-based GB-ILs (blue bars), tetrabutylphosphonium-based GB-ILs (red bars) and GBs (grey bars). A phosphate buffer solution was used as control, regarding the same conditions described for the GB's and GB-ILs samples, namely 4 hours of contact and (a) 0.05 $\mathrm{M}$ and (b) $1.0 \mathrm{M}$. 


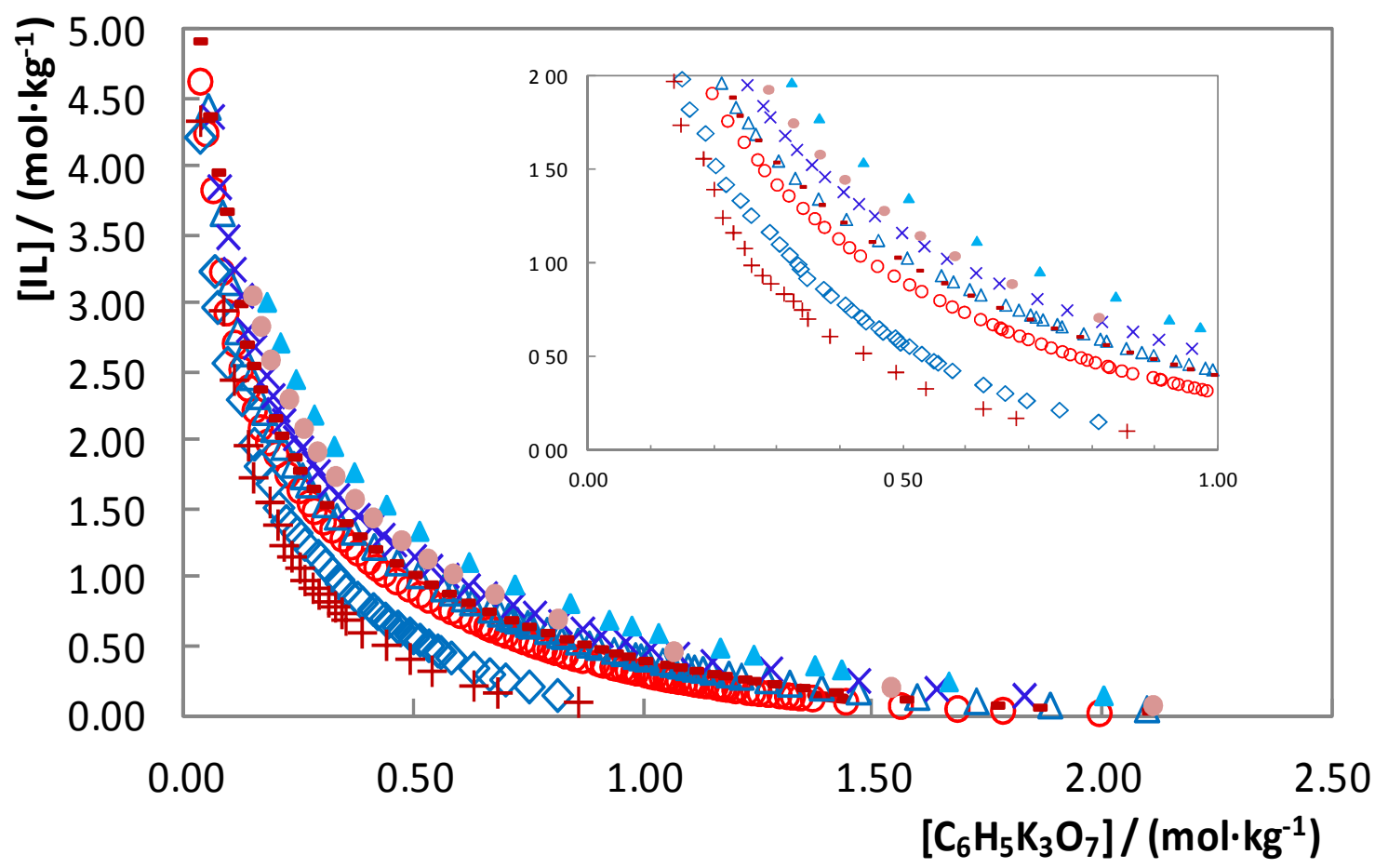

Figure 4. Experimental binodal curves of the systems composed of GB-IL $+\mathrm{K}_{3} \mathrm{C}_{6} \mathrm{H}_{5} \mathrm{O}_{7}+$ water at $25 \pm 1\left({ }^{\circ} \mathrm{C}\right):(\Delta)\left[\mathrm{N}_{4,4,4,4}\right][\mathrm{TAPSO}],(\bullet)\left[\mathrm{P}_{4,4,4,4}\right][\mathrm{TAPSO}],(\times)\left[\mathrm{N}_{4,4,4,4}\right][\mathrm{BES}],(\Delta)$ $\left[\mathrm{N}_{4,4,4,4}\right][\mathrm{MOPSO}], \quad(-) \quad\left[\mathrm{P}_{4,4,4,4}\right][\mathrm{BES}], \quad(\circ) \quad\left[\mathrm{P}_{4,4,4,4}\right][\mathrm{MOPSO}], \quad(\diamond) \quad\left[\mathrm{N}_{4,4,4,4}\right][\mathrm{CAPSO}], \quad(+)$ $\left[\mathrm{P}_{4,4,4,4}\right][\mathrm{CAPSO}]$. 


\section{CATALYTIC REACTION STEP}

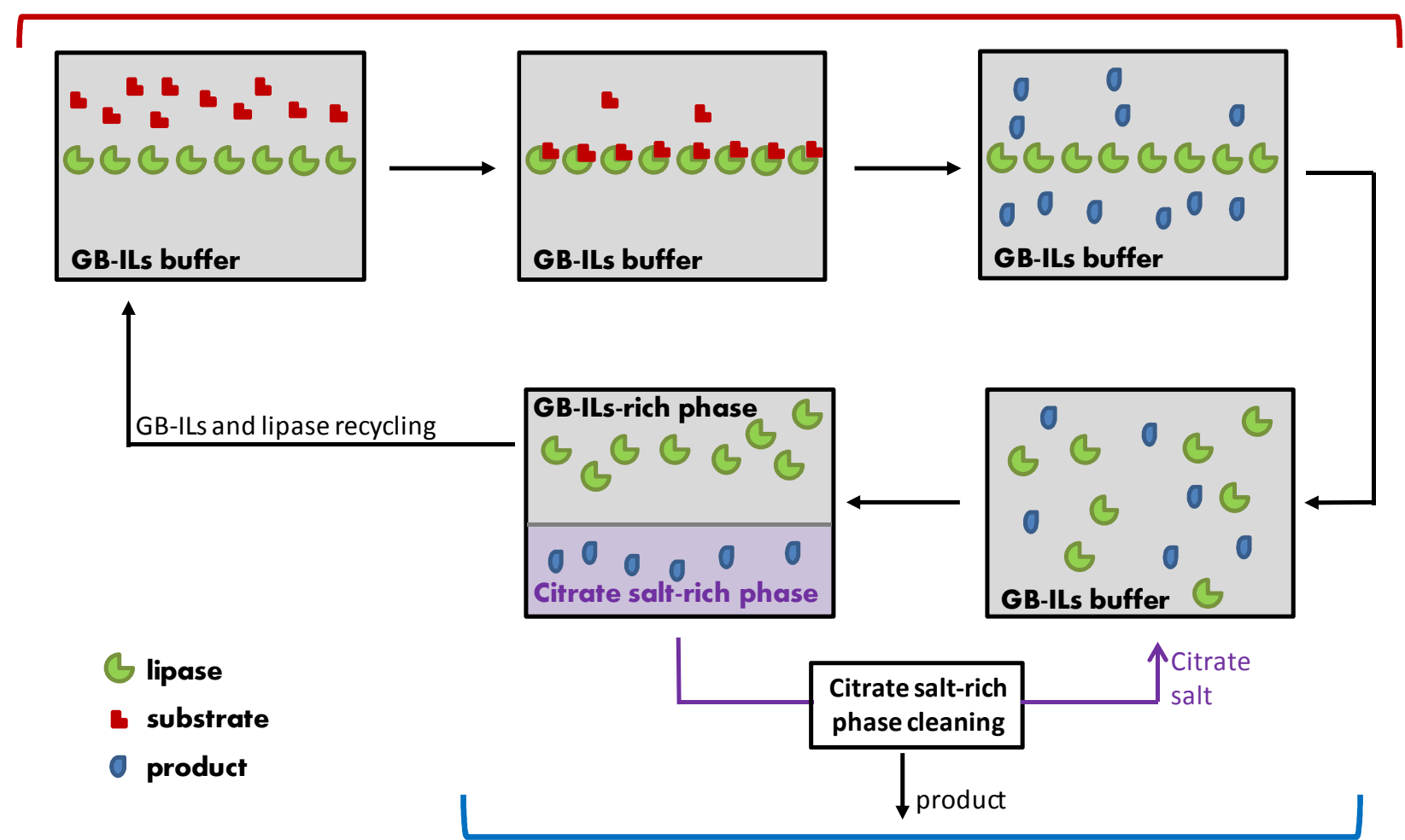

EXTRACTION STEP

Figure 5. Conceptual process diagram of the integrated use of GB-ILs as buffers in a general catalytic reaction and as ABS formers promoting the recovery of the lipase. 
For Table of Contents Use Only

\title{
Evaluating self-buffering ionic liquids for
}

\section{biotechnological applications}

\author{
Sze Ying Lee ${ }^{\mathrm{a}}$, Filipa A. Vicente ${ }^{\mathrm{b}}$, Francisca A. e Silva ${ }^{\mathrm{b}}$, Tânia E. Sintra ${ }^{\mathrm{b}}$, Mohamed Taha ${ }^{\mathrm{b}}$, \\ Ianatul Khoiroh ${ }^{\mathrm{a}}$, João A. P. Coutinho ${ }^{\mathrm{b}}$, Pau Loke Show ${ }^{\mathrm{a}}$, Sónia P. M. Ventura ${ }^{\mathrm{b} *}$

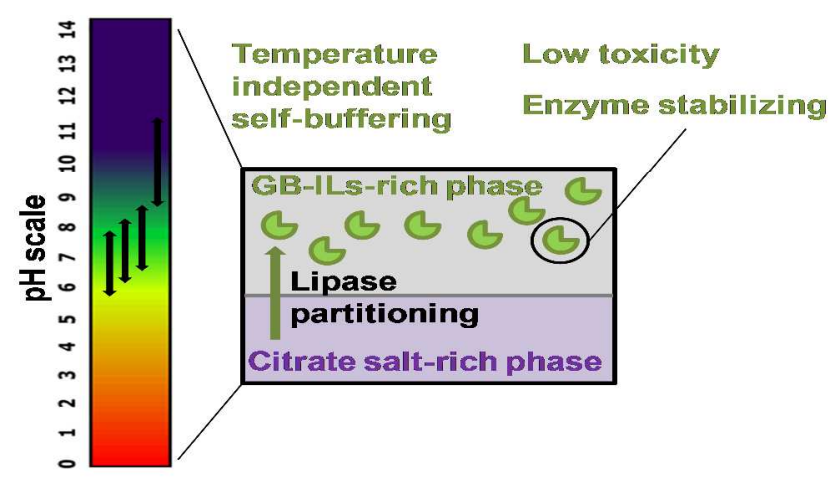

GB-ILs are advantageous compounds to be used as extraction solvents in ABS, allowing their application in enzyme catalysis and in bioseparation technology. 